\title{
Emulsion for Infusion in Administration System
}

National Cancer Institute

\section{Source}

National Cancer Institute. Emulsion for Infusion in Administration System. NCI

Thesaurus. Code C149480.

Medicinal product consisting of an emulsion for infusion presented in an administration system. 